Rev. Biol. Trop. 52(1): 47-55, 2004

www.ucr.ac.cr www.ots.ac.cr www.ots.duke.edu

\title{
Temporal-spatial distribution of the hermit crab Loxopagurus loxochelis (Decapoda: Diogenidae) from Ubatuba Bay, São Paulo State, Brazil
}

\author{
Fernando L.M. Mantelatto ${ }^{1}$, Jussara M. Martinelli ${ }^{1} \&$ Adilson Fransozo ${ }^{2}$ \\ 1 Departamento de Biologia-FFCLRP-Universidade de São Paulo (USP). Av. Bandeirantes, 3900-CEP 14.040-901 \\ Ribeirão Preto (SP), Brasil. Fax: +55 16 6331758; flmantel@usp.br \\ 2 Departamento de Zoologia, Instituto de Biociências, Universidade Estadual Paulista (UNESP)-Rubião Júnior, CEP \\ 18618-000, Botucatu (SP), Brasil. Fax: +55 14 38116268; fransozo@ibb.unesp.br
}

Received 14-III-2001. Corrected 16-V-2002. Accepted 26-IX-2003.

\begin{abstract}
The present work was conducted to determine the distribution of Loxopagurus loxochelis collected monthly, over a period of one year, in Ubatuba Bay (from September/95 to August/96). A total of 179 specimens were collected (138 males, 30 females and 11 ovigerous females). The greatest depth, predominance of very fine sand and highest mean value of organic matter contents of sediment, in combination with the low temperatures registered in winter (July and August), determined the presence of L. loxochelis in the subarea located at the Ubatuba Bay mouth, exposed to the open sea with high water current energy, important because this position insures that spawned larvae will enter into the oceanic circulation.
\end{abstract}

Key words: Crustacea, distribution, hermit crab, Loxopagurus loxochelis.

Studies on the distribution of marine organisms are essential to obtain information about the coastal regions affected by human activity, pollution and water current dynamics. According to Mantelatto et al. (1995), the spatial distribution of marine organisms becomes difficult to understand when the ocean and the complex relationship between abiotic factors are analyzed. For this reason, continuous and detailed studies of species with important role on dynamics of small areas such as bay and inlets, may contribute to the understanding of the distribution mechanism in marine complexes (Mantelatto 2000).

The few studies available about the spatial distribution of hermit crabs and its relationship with environmental factors, were carried out in the second half of the $20^{\text {th }}$ century, and this line of study has been poorly investigated along the Brazilian coast. Important contributions have been made in the Ubatuba region, northern coast of São Paulo State, as part of a long-term effort, undertaken to study the life cycles of decapod crustaceans in this area. Hebling et al. (1994) studied the spatial distribution of Anomura in three adjacent areas of Anchieta Island; Negreiros-Fransozo et al. (1997) investigated the composition and the spatial-temporal distribution of anomuran crabs in Fortaleza Bay; Fernandes-Góes (1997) and Bertini and Fransozo (1999) respectively, investigated the same aspects specifically in the hermit crabs Dardanus insignis (Saussure 1858) and Petrochirus diogenes (Linnaeus 1758) in Ubatuba Bay. Finally, Fransozo et al. (1998) studied the composition and the spatial-temporal distribution of Paguridae, Diogenidae and Porcellanidae crabs in Ubatuba Bay.

Loxopagurus loxochelis (Moreira 1901) is an endemic hermit crab of the Atlantic coast of 
South America, occurring in Brazil (Bahia to Rio Grande do Sul States), Uruguay and Argentina (Melo 1999). The biology of this species is poorly known. Available data deals only with species description and adult distribution (Moreira 1901, Forest and Saint Laurent 1967, Scelzo 1976), larval distribution along the coast of Rio Grande (Rieger and D'Incao 1991), and recently the spermathophore morphology (Scelzo et al., in press). The life cycle of $L$. loxochelis has recently been studied in the Ubatuba region, where the occurrence of exobionts in gastropod shells, shell utilization pattern, relative growth and population structure and breeding season, were investigated by Martinelli and Mantelatto (1998), Martinelli and Mantelatto (1999), Mantelatto and Martinelli (2001), and Martinelli et al. (2002).

The aim of this study was to analyze the temporal-spatial distribution of $L$. loxochelis from Ubatuba Bay, northern coast of São Paulo State, Brazil. The correlation between individuals and abiotic factors was calculated to identify the variables that influence the temporal-spatial distribution of $L$. loxochelis.

\section{MATERIAL AND METHODS}

\section{Study area and sampling}

Ubatuba Bay $\left(23^{\circ} 26^{\prime} \mathrm{S}\right.$ and $\left.45^{\circ} 02^{\prime} \mathrm{W}\right)$ is located along the northern coast of São Paulo State, Brazil. The total area of the bay is $8 \mathrm{~km}^{2}$, and the width is $4.5 \mathrm{~km}$ at the entrance, decreasing landward. This bay can be divided into an inner and outer section (Costa et al. 2000). The inner section is affected by a direct freshwater drainage from four small rivers and consequently, receives a continuous input of domestic sewage and considerable deposition of organic matter. The outer section is exposed to oceanic influence. Detailed descriptions of environmental factors of the Bay, and the study site characteristics can be found in Mantelatto and Fransozo (1999).

A preliminary sampling was carried out during six months to establish a sampling design for the present study. Specimens were collected from eight subareas in the Bay, chosen according to the trawler viability. Biological and environmental data were collected along transects of $1 \mathrm{~km}$ length in each subarea (Fig. 1). Hermit crabs were collected monthly on three consecutive days with double rigged trawl nets $(3.5 \mathrm{~m}$ wide mouth, 10 mm mesh size cod end) from September 1995 to August 1996. Each day, samples were made along eight subareas (1 km transects length) during daylight. Trawling was performed at 1.5 knots for $20 \mathrm{~min}$, sufficient to prevent significant escape from the nets.

After collection, the animals were frozen. In the laboratory, the material was thawed at room temperature and the sex was checked. The absolute abundance was calculated based on the number of hermit crabs recorded in each collecting transect per month, considering the total of all trawls during the three days.

\section{Abiotic factors and analysis of data}

Data concerning environmental factors were obtained before trawling at three points in each subarea. Position of the sampling stations were determined with a Global

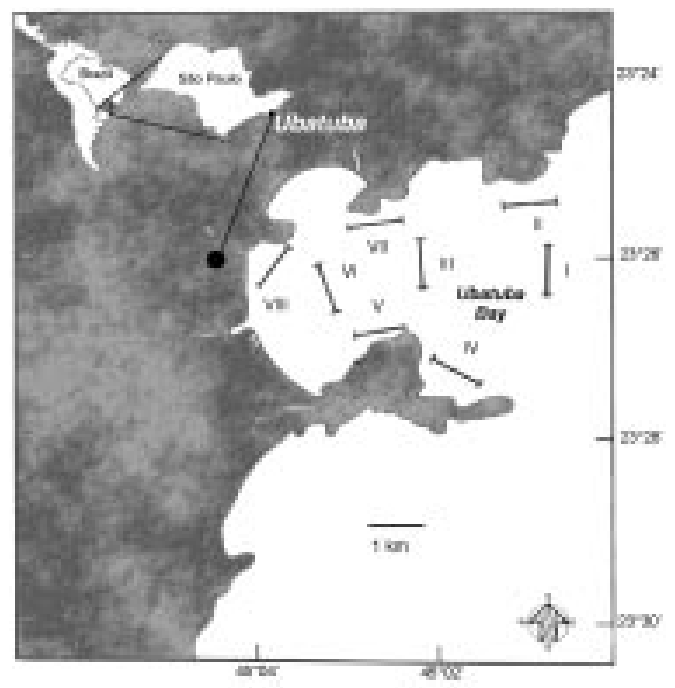

Fig. 1. Map indicating Ubatuba Bay, Ubatuba (São Paulo State), Brazil, and the location of subareas of collection. 
Positioning System (GPS). Bottom water samples were collected with a Nansen bottle and water temperature $\left({ }^{\circ} \mathrm{C}\right)$ was measured with a reversible thermometer attached to the bottle. Salinity (p.s.u.) was determined with an optical refractometer and dissolved oxygen concentration $(\mathrm{mg} / \mathrm{l})$ was determined by the Winckler method (Golterman and Clymo 1969), modified by the addition of sodium azide.

Depth was measured at each sampling station using a graduated rope, attached to the Van-Veen grab sampler $\left(1 / 40 \mathrm{~m}^{2}\right)$, used for sampling the sediment. In the laboratory, $200 \mathrm{~g}$ of sediment were dried at $70^{\circ} \mathrm{C}$ for 72 hours, split into aliquots and used for organic matter and grain size analyses. The Wenthworth (1922) scale was used for the grain size analyses. Percentage of organic matter was obtained by ash-weight: three aliquots of $10 \mathrm{~g}$ each, per subarea (from three stations in each subarea), per month, were placed in porcelain crucibles and submitted to a temperature of $500^{\circ} \mathrm{C}$, over a period of three hours and weighed again. The mean diameter value $(\pi)$ was used, according to Suguio (1973), to calculate the central sediment tendency. To better visualize the results in terms of occurrence of individuals, we grouped the abiotic factors values into size classes.
Pearson's linear correlation was used to determine the existence of correlation between the absolute abundance of the hermit crabs and each environmental factor (depth, temperature, dissolved oxygen, salinity, organic matter and grain size of the sediment). The environmental parameters from eight subareas were compared by ANOVA. The level of significance was determined by the Chi-Square test (Zar 1996).

\section{RESULTS}

\section{Abiotic factors}

The mean salinity during the sampling period was $33.2 \pm 0.35$ p.s.u. The maximum mean $(35.3 \pm 0.35$ p.s.u. $)$ was registered in January/96 and the minimum mean value (29.6 \pm 0.81 p.s.u.) in November/95. There was no significant difference between the subareas sampled. Variations in mean salinity between months were determined, with January, March, April, June, July and August presenting the highest values of salinity (Table 1 ).

There was no significant difference in water temperature among the eight subareas sampled. The annual mean temperature was

TABLE 1

Mean values only for subarea I in Ubatuba Bay, during the period from September 1995 to August 1996*

$\begin{array}{lccccc}\text { Month } & \begin{array}{c}\text { Salinity } \\ \text { (p.s.u.) }\end{array} & \begin{array}{c}\text { Temperature } \\ \left({ }^{\circ} \mathrm{C}\right)\end{array} & \begin{array}{c}\text { Dissolved } \\ \text { oxygen }(\mathrm{mg} / \mathrm{l})\end{array} & \begin{array}{c}\text { Organic } \\ \text { matter }(\%)\end{array} & \begin{array}{c}\text { Depth } \\ (\mathrm{m})\end{array} \\ \text { September 95 } & 32.0 \pm 2.83 & 21.5 \pm 0.19 & 4.93 \pm 0.07 & 2.0 \pm 0.69 & 16.5 \pm 0.50 \\ \text { October 95 } & 32.5 \pm 0.71 & 21.9 \pm 0.13 & 4.35 \pm 0.17 & 51.4 \pm 0.29 & 16.3 \pm 0.47 \\ \text { November 95 } & 31.3 \pm 1.70 & 22.8 \pm 0.22 & 5.32 \pm 0.05 & 4.1 \pm 2.99 & 15.7 \pm 1.25 \\ \text { December 95 } & 32.0 \pm 0.82 & 17.3 \pm 0.45 & 4.32 \pm 0.02 & 2.8 \pm 0.83 & 17.5 \pm 1.47 \\ \text { January 96 } & 35.7 \pm 0.94 & 25.9 \pm 0.28 & 4.66 \pm 0.19 & 2.2 \pm 0.42 & 16.8 \pm 0.62 \\ \text { February 96 } & 32.7 \pm 1.25 & 26.5 \pm 0.15 & 4.92 \pm 0.01 & 2.2 \pm 0.38 & 16.7 \pm 0.47 \\ \text { March 96 } & 34.5 \pm 0.50 & 25.0 \pm 1.97 & 4.68 \pm 0.08 & 1.9 \pm 0.63 & 16.5 \pm 0.50 \\ \text { April 96 } & 35.8 \pm 0.25 & 25.8 \pm 0.53 & 5.14 \pm 0.01 & 4.1 \pm 1.70 & 18.5 \pm 0.50 \\ \text { May 96 } & 34.3 \pm 0.47 & 21.9 \pm 0.38 & 5.13 \pm 0.10 & 3.8 \pm 2.85 & 16.2 \pm 0.24 \\ \text { June 96 } & 34.5 \pm 0.41 & 23.0 \pm 0.06 & 4.46 \pm 0.00 & 7.4 \pm 4.55 & 14.7 \pm 0.94 \\ \text { July 96 } & 35.2 \pm 0.24 & 19.8 \pm 0.21 & 5.10 \pm 0.17 & 19.2 \pm 5.09 & 17.0 \pm 0.50 \\ \text { August 96 } & 34.5 \pm 0.50 & 19.2 \pm 0.10 & 5.21 \pm 0.41 & 11.4 \pm 1.27 & 17.0 \pm 1.00\end{array}$

*Almost all (88\%) individuals were captured in this subarea. 
$23.8 \pm 0.62^{\circ} \mathrm{C}$. The lowest mean values were registered in winter $\left(20.2 \pm 0.25^{\circ} \mathrm{C}\right.$ on July; $19.6 \pm 0.33^{\circ} \mathrm{C}$ on August) and the highest values in summer (January $26.6 \pm 0.46^{\circ} \mathrm{C}$; February $27.9 \pm 0.81^{\circ} \mathrm{C}$; March $27.4 \pm$ $\left.1.04^{\circ} \mathrm{C}\right)$.

Dissolved oxygen presented low variations among subareas and months. The annual mean value was $5.11 \pm 0.29 \mathrm{mg} / \mathrm{l}$. Subareas V and VIII presented the highest mean values $(5.51 \pm 0.54$ and $5.47 \pm 0.60 \mathrm{mg} / \mathrm{l}$, respectively), and differ significantly $(\mathrm{p}<0.05)$ of the lowest mean registered in subarea III (4.61 \pm $0.62 \mathrm{mg} / \mathrm{l})$. The subarea II presented the widest range (3.59 to $6.70 \mathrm{mg} / \mathrm{l})$. By month, the highest mean occurred in March $(5.90 \pm 0.67 \mathrm{mg} / \mathrm{l})$ and the lowest in June $(4.28 \pm 0.47 \mathrm{mg} / \mathrm{l})$. The mean temperatures of December/95, January, February, March, May and April/96 differs significantly $(\mathrm{p}<0.05)$ from other months.

The mean values of organic matter content did not differ significantly throughout the study. The highest mean value was registered in October/95 $(17.0 \pm 8.36 \%)$ and the lowest $(8.9 \pm 6.11 \%)$ in $\mathrm{March} / 96$.

Mean depth differed significantly among subareas. The greatest depth $(16.60 \pm 0.89 \mathrm{~m})$ was found in subarea I, and the lowest in subarea VIII $(3.10 \pm 0.31 \mathrm{~m})$. There was no significant difference among subareas II (11.4 \pm
$0.62 \mathrm{~m})$, III $(10.7 \pm 0.72 \mathrm{~m}), \mathrm{V}(7.9 \pm 1.11 \mathrm{~m})$, VI $(7.6 \pm 0.52 \mathrm{~m})$ and VII $(7.3 \pm 0.42 \mathrm{~m})$.

The sediment presented fractions of gravel to silt + clay. There was no difference in sediment composition for the same subarea during the months of sampling. The central tendency of sediment presented differences among subareas. Three groups were distinguished: subareas I, II, VII and VIII had a predominance of very fine sand, while subareas III and VI presented, basically fine sand. Subareas IV and V consisted of medium sand.

Distribution of $L$. loxochelis: A total of 288 trawls were performed in Ubatuba Bay during the study. From a total of 179 specimens of L. loxochelis collected, there was 138 males, 30 females and 11 ovigerous females. No young hermit crabs (specimens with shield length $<3.2 \mathrm{~mm}$ ) (Mantelatto and Martinelli 2001) were found in this region.

The highest incidence of males, females and ovigerous females $(87.70 \%$ of the total) occurred in subarea I (outer section of the Bay), with a total of 157 individuals (Table 2). In the subareas II and III, only five hermit crabs were collected. Subareas VI, VII and VIII presented $6.15 \%$ of the total number of individuals and no specimen was found in subareas IV and V. The highest occurrence of $L$. loxochelis in subarea I was in July and August,

TABLE 2

Number of specimens of Loxopagurus loxochelis collected in each subarea in Ubatuba Bay from September 1995 to August 1996

\begin{tabular}{|c|c|c|c|c|c|c|c|c|c|}
\hline \multirow[t]{2}{*}{ Month } & \multicolumn{8}{|c|}{ Subarea } & \multirow[t]{2}{*}{ Total } \\
\hline & I & II & III & IV & V & VI & VII & VIII & \\
\hline September 95 & 9 & - & 2 & - & - & - & 1 & - & 12 \\
\hline October 95 & 11 & - & - & - & - & - & - & - & 11 \\
\hline November 95 & 2 & - & - & - & - & 1 & - & 3 & 6 \\
\hline December 95 & 5 & 1 & - & - & - & - & - & - & 6 \\
\hline January 96 & 10 & - & 1 & - & - & - & - & - & 11 \\
\hline February 96 & - & - & - & - & - & - & - & - & - \\
\hline March 96 & - & 1 & - & - & - & - & - & - & 1 \\
\hline April 96 & 3 & - & - & - & - & - & 1 & - & 4 \\
\hline May 96 & 5 & 1 & - & - & - & 1 & - & - & 7 \\
\hline June 96 & - & - & - & - & - & - & - & - & \\
\hline July 96 & 66 & - & 2 & - & - & 1 & 1 & - & 70 \\
\hline August 96 & 46 & 2 & 1 & - & - & 1 & - & 1 & 51 \\
\hline Total & 157 & 5 & 6 & - & - & 4 & 3 & 4 & 179 \\
\hline
\end{tabular}


a unique combination between month/subarea with high salinity, dissolved oxygen, and organic matter in the sediment associated with the low temperatures was responsible of this fact (Table 1). Ovigerous females occurred only in subarea I, with the highest incidence $(67.78 \%)$ occurring in the winter months (July and August).

The relative percentage of individuals per catch, in each environmental factor class, can be observed in Figure 2. The animals showed the highest occurrence at great depths (14 to $17 \mathrm{~m}$ ), high salinity (34 to 36 p.s.u.), lower temperature $\left(17\right.$ to $\left.20^{\circ} \mathrm{C}\right)$, satisfactory dissolved oxygen (4 to $6 \mathrm{mg} / \mathrm{l}$ ), sediment composed of very fine sand and organic matter content between $1-10 \%$ and $10-20 \%$, respectively.

The associations between environmental factors and abundance of individuals can be seen in Table 3, as calculated by Pearson's correlation coefficient. There was a significant correlation only between occurrence of females and temperature.

\section{DISCUSSION}

According to Mantelatto and Fransozo (1999), the results of abiotic factors obtained from Ubatuba Bay were similar to previous results for others bays in this region, such as those reported by Forneris (1969) for Flamengo Bay and by Abreu (1980) and Negreiros-Fransozo et al. (1991) for Fortaleza Bay. This similarity between the areas occurs in function of similar geographic characteristics and because this region is affected by three water masses (Coastal Water, Tropical Water, and South Atlantic Central Water) with different distributional patterns in the summer and winter (Castro Filho et al. 1987). The dynamics of these currents are responsible for seasonal alterations of temperature, salinity and nutrients concentrations (Costa et al. 2000).

The highest occurrence of L. loxochelis in subarea I (outer section) of Ubatuba Bay was probably related to a group of factors, i.e. the texture of sediment, organic matter content, and temperature. In this subarea, on July and August, was registered the highest values of salinity, dissolved oxygen and organic matter content, combined with the lowest temperature in relation to the other months of collection. This species were also reported in other bays of Ubatuba region, with similar abiotic factors.

The absence of L. loxochelis in subareas IV and $\mathrm{V}$ may be associated with the texture of

TABLE 3

Pearson's linear correlation coefficients for all the specimens of Loxopagurus loxochelis captured and abiotic factors

\begin{tabular}{lcccc} 
Parameter & \multicolumn{4}{c}{ Variable } \\
& Males & Females & Ovigerous females & Total \\
& & & & \\
Dissolved oxygen & 0.326 & 0.348 & 0.351 & 0.334 \\
Temperature & -0.481 & $-0.712^{*}$ & -0.534 & -0.510 \\
Salinity & 0.330 & 0.166 & 0.358 & 0.322 \\
Depth & 0.204 & 0.198 & 0.393 & 0.218 \\
Organic matter & 0.317 & 0.205 & 0.158 & 0.301 \\
Sediment & & & & \\
Gravel & -0.013 & -0.208 & 0.019 & -0.028 \\
Very coarse sand & 0.307 & 0.111 & 0.327 & 0.295 \\
Coarse sand & 0.191 & 0.053 & 0.255 & 0.185 \\
Medium sand & 0.178 & 0.211 & 0.375 & 0.196 \\
Fine sand & -0.007 & -0.030 & 0.069 & -0.04 \\
Very fine sand & -0.418 & -0.376 & -0.530 & -0.426 \\
Silt + clay & 0.464 & 0.541 & 0.509 & 0.479
\end{tabular}


sediment present in these sites, with predominance of medium sand, a less favorable substrate for the burrowing of these hermit crabs (personal observation under laboratory conditions). The low occurrence of specimens in subareas VI, VII, and VIII can be considered as accidental, probably because fishers sort their catch and throw unwanted items overboard in these locations, before taking them to a commercial landing site, consequently introducing new hermit specimens (Mantelatto et al. 2001).
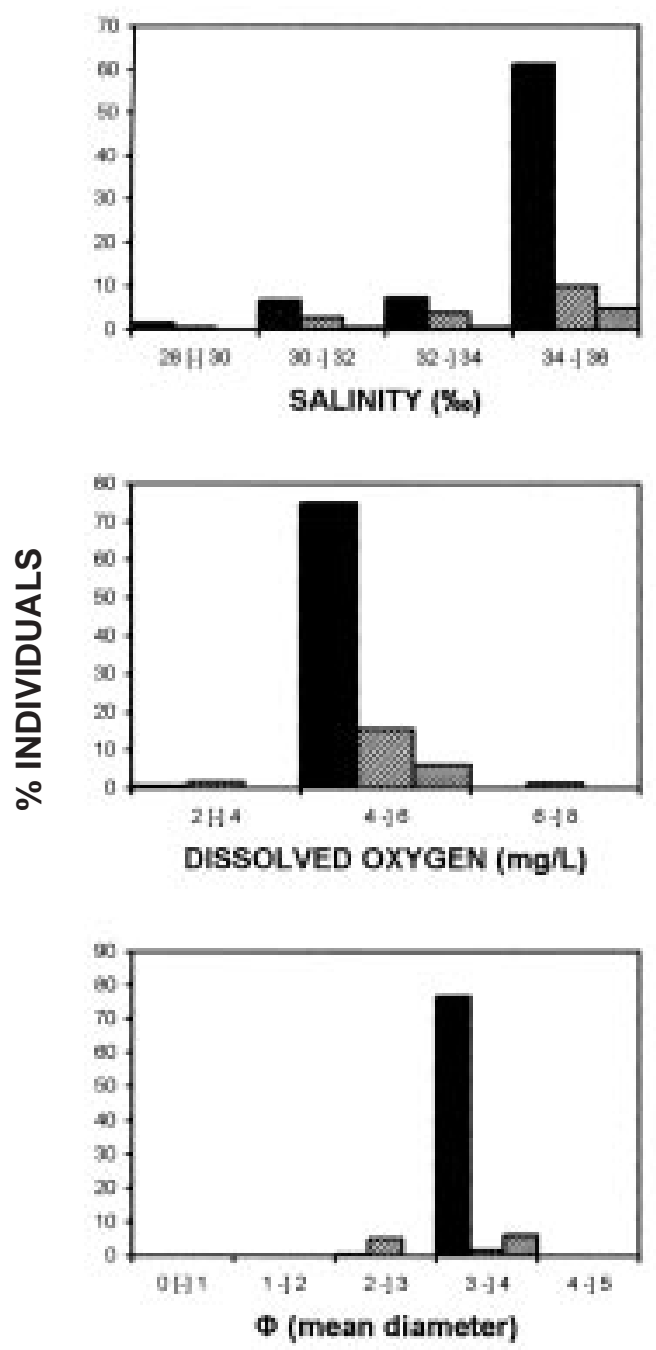

The size and nature of sediment are important factors that determine the selection of habitat by crustaceans (Teal 1958, Cobb 1971). Although regarded as suspension feeders, L. loxochelis were mainly captured in areas with low organic matter contents and were more abundant in deeper areas, not affected by freshwater drainage in Ubatuba Bay. In addition, since L. loxochelis is a filtering animal, it is capable of burrowing in sediment, like other hermit crabs (Caine 1978, Schembri 1988). These conditions, associated
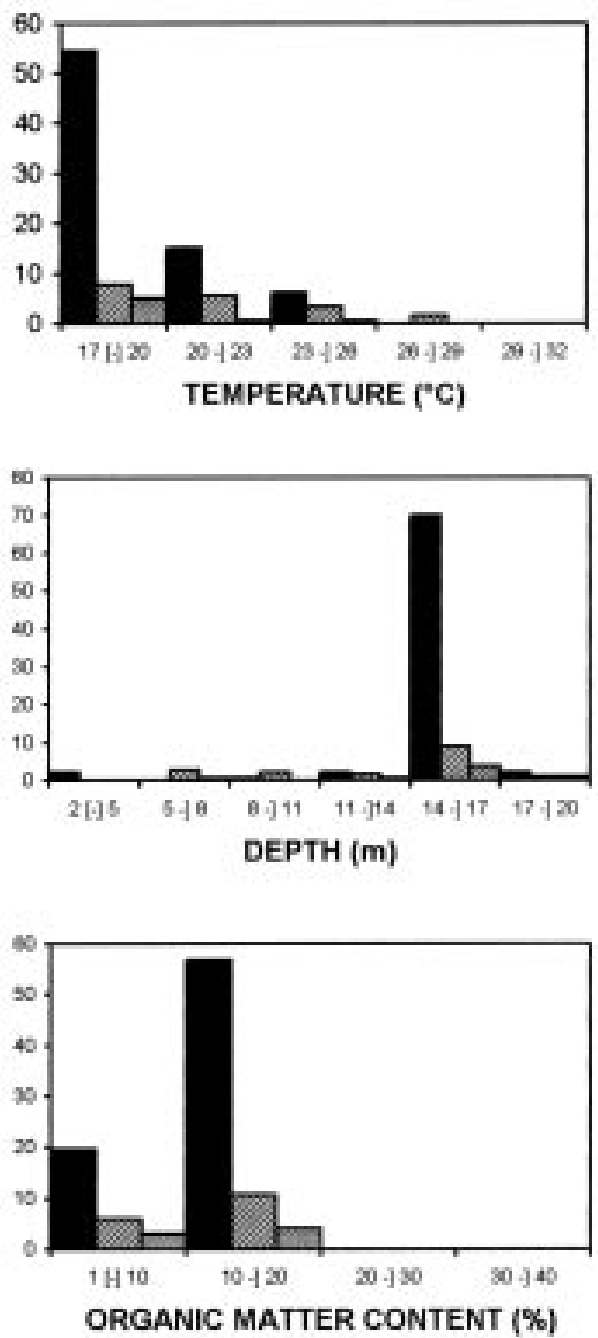

Fig. 2. Relative percentage of specimens of L. loxochelis collected in Ubatuba Bay from September 1995 to August 1996 $(\mathrm{n}=179)$, in relation to classes of abiotic factors analyzed $(\square=$ Males; $\mathbb{Q}=$ Females; $\square=$ Ovigerous females). 
with the presence of very fine sand, can be an important reason for the higher occurrence of L. loxochelis in subarea I, principally in July and August, when temperature and organic matter content were the most outstanding factors. Thus, these parameters, taken as a whole, were the principal reason that determined the occurrence of L. loxochelis in Ubatuba Bay. In addition to this hypothesis, L. loxochelis is a filtering animal needing a great quantity of particles in suspension, that are provided during the coldest months (winter) by the change of marine currents in the Ubatuba region (Castro Filho et al. 1987). In this way, sediment texture and organic matter content can be related to the diet of hermit crabs and also constitutes the main factors that influence the temporalspatial distribution of $L$. loxochelis in Ubatuba Bay.

The relation between abiotic factors and L. loxochelis, mainly in terms of temperature, may indicate that females search deeper areas during the reproductive period. According to Reese (1968), the degree of variation in reproductive activity is a result of ecological adaptations in different areas, where the temporal pattern of egg hatching can not be generalized when only one kind of factor is analyzed. Perhaps, hermits were most abundant at the mouth of the bay, because this position insures that spawned larvae will enter oceanic circulation, as mentioned for the ovigerous females of the portunid $C$. ornatus in the same bay (Mantelatto 2000). This would explain why they were especially abundant in subarea I during spawning season.

Biotic factors like predation and competition for shells, which were not considered in this study, possibly affects the distribution of L. loxochelis in Ubatuba Bay. Although several species of hermits live on non-consolidated substrates (Hebling et al. 1994, Fransozo et al. 1998), only $D$. insignis and $P$. diogenes were found at lower temperatures, as also observed for L. loxochelis, but in different subareas of Ubatuba Bay. According to Martinelli and Mantelatto (1999), this represents avoidance of competition for empty gastropod shells. In addition, the possibility of competition for food among them has been ruled out as a function of the differences in the diets of these species.

Another important hypothesis that can be considered is the geographic distribution of this species. Although the presence of L. loxochelis has been registered in the Bahia littoral, Northeast of Brazil (Melo 1999), the occurrence of this species is mainly in the southern littoral of Brazil and Argentina, where the water temperature is commonly lower during almost all months. The occurrence of $L$. loxochelis in Ubatuba region represents the final point of northern distribution for this species and can be its real limit. The specimens from Bahia probably were misreported. This hermit species was the most abundant in Fortaleza Bay (Negreiros-Fransozo et al. 1997) and Anchieta Island (Hebling et al. 1994), both areas in the Ubatuba region. Probably, L. loxochelis is adapted to reproduce in waters with low temperatures $\left(17-20^{\circ} \mathrm{C}\right)$, a fact corroborated by the high presence of ovigerous females and larval stages along the Rio Grande coast, reported by Rieger and D'Incao (1991) and ovigerous females in Ubatuba region during the winter, reported by Hebling et al. (1994), Negreiros-Fransozo et al. (1997), and Martinelli et al. (2002). So, this species found the temperature and food conditions for reproduction in Ubatuba Bay during the winter (July - August), a period with a high occurrence of males, who probably are there to find females for the reproductive process. A comparative investigation between the populations from south and southeast regions of Brazil could elucidate these aspects in the future.

\section{ACKNOWLEDGMENTS}

JMM is grateful to the Conselho Nacional de Desenvolvimento Científico e Tecnológico (CNPq) for a Master's Scholarship (\# 136227/96-1). FLMM is indebted to "Fundação de Amparo a Pesquisa do Estado de São Paulo (FAPESP)" (Grant 95/2833-0) for 
financial support to the project. We also thank many colleagues from NEBECC for their help in the field and in the laboratory. Special thanks are due to Nilton José Hebling (Paulista State University) and to anonymous referees for assistance and helpful criticism on early draft of the manuscript. We also thank Rafael Robles for Spanish translation of the "resumen".

\section{RESUMEN}

Se realizó un estudio de la distribución espacial y temporal de la especie Loxopagurus loxochelis, en función de algunos factores abióticos, en la ensenada de Ubatuba, Brasil. Las capturas fueron realizadas con una red de arrastre mensualmente, entre Septiembre de 1995 y Agosto de 1996, en ocho transectos determinados previamente. Se obtuvieron un total de 179 individuos 138 machos, 30 hembras y 11 hembras ovígeras. La combinación de algunos factores fueron determinantes del alto número de individuos capturados en el área externa da la ensenada, la cual sufre la influencia de las corrientes marinas favorables a la dispersión de las larvas. Estos factores fueron la profundidad, el diámetro de la arena, la concentración de materia orgánica y la temparatura.

\section{REFERENCES}

Abreu, J. 1980. Distribuição e ecologia dos Decapoda numa área estuarina de Ubatuba (SP). Bol. Inst. Oceanogr. 29: 1-3.

Bertini, G. \& A. Fransozo. 1999. Spatial and seasonal distribution of Petrochirus diogenes (Anomura, Diogenidae) in the Ubatuba Bay, São Paulo, Brazil. Iheringia, Sér. Zool. 86: 145-150.

Caine, E.A. 1978. Habitat adaptation of Isocheles wurdemanni Stimpson (Crustacea: Anomura: Diogenidae) and seasonality of occurrences in Northwestern Florida. Contrib. Mar. Sci. 21: 117-123.

Castro Filho, B.M, L.B. Miranda \& S.Y. Myao. 1987. Condições hidrogeográficas na plataforma continental ao largo de Ubatuba: variações sazonais e em média escala. Bol. Inst. Oceanogr. 35: 135-151.

Cobb, J.S. 1971. The shelter-related behavior of the lobster, Homarus americanus. Ecology 52: 108-115.

Costa, R.C., A. Fransozo, F.L.M. Mantelatto \& R.H. Castro. 2000. Occurrence of shrimp species (Crustacea: Decapoda: Natantia: Penaeidea and Caridea) in Ubatuba Bay, Ubatuba, SP, Brazil. Proc. Biol. Soc. Wash. 113: 776-781.
Fernandes-Góes, L.C. 1997. Distribuição e biologia populacional de Dardanus insignis (Saussure, 1858) (Crustacea: Decapoda: Anomura) na região de Ubatuba, São Paulo. Master Thesis, Paulista State University, Brazil. 150 p.

Forest, J. \& M. Saint Laurent. 1967. Campagne de la Calypso au large des côtes atlantiques de l'Amérique du Sud (1961-1962). Crustacés Décapodes: Pagurides. Ann. Inst. Oceanogr. 45: 47-169.

Forneris, L. 1969. Fauna bentônica da Baía do Flamengo, Ubatuba, SP: aspectos ecológicos. Ph.D. Thesis, University of São Paulo, Brazil. 215 p.

Fransozo, A., F.L.M. Mantelatto, G. Bertini, L.C. Fernandes-Góes \& J.M. Martinelli. 1998. Distribution and assemblages of anomuran crustaceans in Ubatuba Bay, North coast of São Paulo State, Brazil. Acta Biol. Venez. 18: 17-25.

Golterman, H.L. \& R.S. Clymo. 1969. Methods for chemical analysis of freshwaters. Blackwell, Oxford. $116 \mathrm{p}$.

Hebling, N.J., F.L.M. Mantelatto, M.L. NegreirosFransozo \& A. Fransozo. 1994. Levantamento e distribuição de braquiúros e anomuros (Crustacea, Decapoda) dos sedimentos sublitorais da região da Ilha Anchieta, Ubatuba (SP). B. Inst. Pesca 21: 1-9.

Mantelatto, F.L.M. 2000. Allocation of the portunid crab Callinectes ornatus (Decapoda: Brachyura) in Ubatuba Bay, northern coast of São Paulo State, Brazil. Crust. Issues 12: 431-443.

Mantelatto, F.L.M \& A. Fransozo. 1999. Characterization of the physical and chemical parameters of Ubatuba Bay, northern coast of São Paulo State, Brazil. Revta. Brasil. Biol. 59: 23-31.

Mantelatto, F.L.M. \& J.M. Martinelli. 2001. Relative growth and sexual dimorphism of the South Atlantic hermit crab Loxopagurus loxochelis (Anomura, Diogenidae) from Ubatuba, Brazil. J. Nat. Hist. 35: 429-437.

Mantelatto, F.L.M., A. Fransozo \& M.L. NegreirosFransozo. 1995. Population structure of Hepatus pubidundus (Decapoda: Calappidae) in Fortaleza Bay, Brazil. Rev. Biol. Trop. 43: 265-270.

Mantelatto, F.L.M., R.B. Garcia, J.M. Martinelli \& N.J. Hebling. 2001. On a record of Dardanus venosus $(\mathrm{H}$. Milne Edwards) (Crustacea, Anomura) from the São Paulo State, Brazil. Revta. Bras. Zool. 18 (1): 71-73.

Martinelli, J.M. \& F.L.M. Mantelatto. 1998. Occurrence of exobionts in gastropod shells occupied by the hermit crab Loxopagurus loxochelis (Anomura: Diogenidae) in Ubatuba Bay (SP), Brazil, pp. 221- 
226. In Anonymous (ed.). Anais do IV Simpósio de Ecossistemas Brasileiros. ACIESP, São Paulo, Brazil.

Martinelli, J.M. \& F.L.M. Mantelatto. 1999. Shell occupation by the hermit crab Loxopagurus loxochelis (Moreira, 1901) (Anomura: Diogenidae) from Ubatuba Bay, Brazil, pp. 719-731. In F.R. Schram \& J.C. Vaupel Klein (eds.). Crustaceans and the Biodiversity Crisis. Brill, Leiden, The Netherlands.

Martinelli, J.M., F.L.M. Mantelatto \& A. Fransozo. 2002 Population structure and breeding season of the South Atlantic hermit crab, Loxopagurus loxochelis (Anomura, Diogenidae) from Ubatuba region, Brazil. Crustaceana 75 (6): 791-802.

Melo, G.A.S. 1999. Crustacea Decapoda do litoral brasileiro: Anomura, Thalassinidae, Palinuridae e Astacidae. Plêiade, São Paulo, Brazil. 551 p.

Moreira, C. 1901. Contribuições para o conhecimento da fauna brasileira. Crustáceos do Brasil. Arch. Mus. Nac. Rio Janeiro 11: 1-151.

Negreiros-Fransozo, M.L., A. Fransozo, M.A.A. Pinheiro, F.L.M. Mantelatto \& S. Santos. 1991. Caracterização física e química da Ensenada da Fortaleza, Ubatuba (SP). Rev. Brasil. Geoc. 21: 114-120.

Negreiros-Fransozo, M.L., A. Fransozo, F.L.M. Mantelatto, M.A.A. Pinheiro \& S. Santos. 1997. Anomuran species (Crustacea, Decapoda) and their ecological distribution at Fortaleza Bay sublittoral, Ubatuba, São Paulo, Brazil. Iheringia, Sér. Zool. 83: 187-194.
Reese, E. 1968. Annual breeding seasons of three sympatric species of tropical intertidal hermit crabs, with a discussion of factors controlling breeding. J. Exp. Mar. Biol. Ecol. 2: 308-318.

Rieger, P.J. \& F. D'Incao. 1991. Distribuição das larvas de Loxopagurus loxochelis (Decapoda, Diogenidae) na região adjacente à Barra de Rio Grande, RS. Nerítica, 6: 93-106.

Scelzo, M.A. 1976. Larvas de los crustáceos decápodos anomuros identificadas en las aguas marinas Argentinas. Physis 35: 37-45.

Scelzo, M.A., F.L.M. Mantelatto \& C. Tudge. 2004. Spermatophore morphology of the hermit crab Loxopagurus loxochelis (Moreira, 1901) (Anomura, Diogenidae) from the Southwestern Atlantic. Invert. Reprod. Develop. in press.

Schembri, P.J. 1988. Bathymetric distribution of hermit crabs (Crustacea: Decapoda: Anomura) from the Otago region, southeastern New Zealand. J. Roy. Soc. New Zeal. 18: 91-102.

Suguio, K. 1973. Introdução a Sedimentologia. EDUSP, São Paulo, Brazil. 317 p.

Teal, J.M. 1958. Distribution of fiddler crabs in Georgia salt marshes. Ecology 39: 185-193.

Zar, J.H. 1996. Bioestatistical Analysis. Prentice Hall, New Jersey, USA. 662 p.

Wenthworth, C.H. 1922. A scale of grade and class terms for classic sediments. J. Geol. 30: 377-392. 
